\title{
Utility of Underwater Weenie Life Forms as Voluminous Organisms: A Review
}

\author{
Rout George Kerry ${ }^{1}$, Samprit Padhiary ${ }^{1}$, Gyana Prakash Mahapatra² and Jyoti Ranjan Rout ${ }^{3 *}$ \\ 1Department of Biotechnology, Academy of Management and Information Technology, \\ 67/68, IID Centre, BidyaVihar, Barunei Hills, Khurda 752057, Odisha, India. \\ ${ }^{2}$ Centre of Advanced Study in Marine Biology, Annamalai Universit \\ Parangipettai, 608502, Tamilnadu, India. \\ ${ }^{3}$ School of Biological Sciences, Asian Institute of Public Health, \\ 28A, Unit-VI, Ganganagar, Bhubaneswar, 751001, Odisha, India \\ Email: routjr@gmail.com
}

\begin{abstract}
Coral reefs are a sundry subaqueous ecological community, combined with the calcium carbonate structures secreted by converting the carbon dioxide present in the water into limestone. The biotic portion of the coral reef is marine animal known as polyps that have resemblance with jellyfish. Unlike terrestrial environment, the marine component is tightly interdependent. Taking out one component or loss of from a system can have a devastating impact or undermine the entire marine ecosystem. Reefs specifically are a vital organism among underwater life which is dependent on corals and provide key microhabitat, shelter and breeding ground for thousands of species of fish, crustaceans, mollusks, etc. Coral reef possesses vital ethnobotanical properties, which cures asthma, arthritis, and even cancer. Apart from medicinal properties, further it provides $2 / 3^{\text {rd }}$ of oxygen on earth. However, the destructive fishing practices, pollution and ocean acidification have endangered this kingdom and have led to the threatening of the entire fabric of the underwater life. As human beings are also dependent up to much extent for centuries, there is a high probability of being severely affected if the coral reef extinct leaving the seabed barren. Corals cover almost $1 \%$ of the oceans present on earth, but the irony is $75 \%$ of them are on a verge of extinction. Therefore, the present review focuses on its conservation, cultivation and significance of their application in the field of biomedical science.
\end{abstract}

Keywords: Coral reef, endangered, ethnobotany, extinction, marine ecosystem, pollution.

\section{Introduction}

It can be appositely cited as "what can be explored is little and what remains unexplored is humongous". The earth comprising of almost $70 \%$ of water, in which more than $80 \%$ of living kingdoms are found out of our planet (Malve, 2016). Over the period of years and yet to be discovered, the sea has embraced an enormous trench of corals, shaped by polyps which tentacle containing sea animals and secretes aragonite to create the reef. Tentacles comprise of nematocysts, allowing the polyps to capture small organism for growth and nutrition. As a whole, it can be stated that corals as marine structures, algal symbionts and calcifying coral animals, rightly known as rainforests of the sea. These corals belonging to the phylum Cnidaria which are branched into hard or reef, soft or flexible and gorgonian corals consisting of gorgonin (Cooper et al., 2014). Deflection in the $\mathrm{pH}$ seriously affects growth, survivability and dissociation of the polyps (modular units of the corals) by inducing coral apoptosis. Furthermore in normal condition, the polyps started calcification and hence can rightly be termed as modular units (Kvitt et al., 2015). Some corals are also holobionts in nature with endosymbiotic dinoflagellates, bacterial and viral acquaintances (Krediet et al., 2013). However, every year approximately 200 species of both hard and soft corals are evident to be used for diversified pharmaceutical purposes (Rocha et al., 2011). Henceforth, the corals are essential not only to the sustainability of the reef bionetwork but also to the benefaction of humans.

These underwater weenie life forms contain various bioactive compounds which have cytotoxic, anti-inflammatory and anti-bacterial activities (Table 1). Eight different kinds of steroids are known to be produced by corals which include $5 \alpha$-pregna-20-en3-one, $\quad 5 \alpha$-pregna-1,20-dien-3-one, $\quad 5 \alpha, 8 \alpha$ -

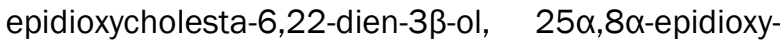

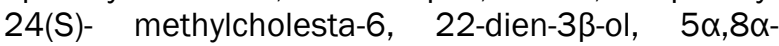
epidioxy-24(R)-methylcholesta-6, 22-dien-3 3 -ol, $5 \alpha, 8 \beta$-epidioxycholesta-6-en-3 $\beta$-ol, $5 \alpha, 8 \beta$ - epidioxy-

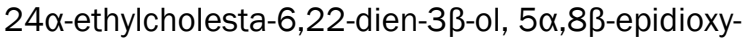


ILMU KELAUTAN June 2018 Vol 23(2):99-108

Table 1. Description of important species of corals and their bioactive compounds with pharmacological properties.

\begin{tabular}{|c|c|c|c|c|}
\hline Name/ Group & Bioactive Compounds & Chemistry & $\begin{array}{c}\text { Pharmacological activity } \\
\text { (Drug Class) }\end{array}$ & References \\
\hline Pinnigorgia sp. & $\begin{array}{l}\text { Pinnisterols } \\
\text { Secosterols }\end{array}$ & Steroid & $\begin{array}{l}\text { Neutrophil superoxide and elastase } \\
\text { inhibition } \\
\text { (Anti-inflammatory and Cytotoxicity) }\end{array}$ & $\begin{array}{l}\text { Chang et al., 2016a } \\
\text { Chang et al., 2017a }\end{array}$ \\
\hline $\begin{array}{l}\text { Briareum } \\
\text { asbestinum }\end{array}$ & Briarenolides & Terpenoid & $\begin{array}{l}\text { Macrophage COX-2 and iNOS } \\
\text { expression inhibition } \\
\text { (Anti-inflammatory) }\end{array}$ & Su et al., 2015 \\
\hline Briareum sp. & Briarenolides & Terpenoid & $\begin{array}{l}\text { Macrophage COX-2 and iNOS } \\
\text { expression inhibition } \\
\text { (Anti-inflammatory) }\end{array}$ & Su et al., 2016 \\
\hline $\begin{array}{l}\text { Sarcophyton } \\
\text { glaucum }\end{array}$ & Isoprenoids & Steroid & $\begin{array}{l}\text { Inhibition of cancer cell proliferation } \\
\text { (Cytotoxicity, Antimicrobial, } \\
\text { Neuroprotective) }\end{array}$ & Chao et al., 2017 \\
\hline $\begin{array}{l}\text { Nephthea } \\
\text { columnaris }\end{array}$ & 5,6-epoxylitosterol & Steroid & $\begin{array}{l}\text { Neutrophil superoxide and elastase } \\
\text { inhibition } \\
\text { (Anti-inflammatory) }\end{array}$ & Whuang et al., 2017 \\
\hline $\begin{array}{l}\text { Sinularia } \\
\text { brassica }\end{array}$ & Sinubrasones & Steroid & $\begin{array}{l}\text { Neutrophil superoxide and elastase } \\
\text { inhibition, Inhibition of cancer cell } \\
\text { proliferation } \\
\text { (Anti-inflammatory and Cytotoxicity) }\end{array}$ & Huang et al., 2017 \\
\hline $\begin{array}{l}\text { Sinularia } \\
\text { leptoclados }\end{array}$ & Sinuleptolide & Steroid & $\begin{array}{l}\text { Inhibition of cancer cell proliferation } \\
\text { (Anti-inflammatory and Cytotoxicity) }\end{array}$ & Chang et al., 2017b \\
\hline $\begin{array}{l}\text { Sinularia } \\
\text { nanolobata }\end{array}$ & Cubitanoids & Terpenoid & $\begin{array}{l}\text { Nitric oxide (NO) inhibition } \\
\text { (Cytotoxicity) }\end{array}$ & Chao et al., 2016 \\
\hline $\begin{array}{l}\text { Umbellulifera } \\
\text { petasites }\end{array}$ & Petasitosterones & Steroid & $\begin{array}{l}\text { Inhibition of cancer cell proliferation } \\
\text { (Anti-inflammatory and Cytotoxicity) }\end{array}$ & Huang et al., 2016 \\
\hline $\begin{array}{l}\text { Sarcophyton } \\
\text { glaucum }\end{array}$ & Glaucumolides & Terpenoid & $\begin{array}{l}\text { Macrophage COX-2 and iNOS } \\
\text { expression inhibition (Anti-inflammatory } \\
\text { and Cytotoxicity) }\end{array}$ & Huang et al., 2015 \\
\hline Euplexaura sp. & Euplexaurenes & Terpenoid & $\begin{array}{l}\text { Cytotoxic activities against human } \\
\text { laryngeal carcinoma } \\
\text { (Antibacterial) }\end{array}$ & Cao et al., 2017 \\
\hline Pinnigorgia sp. & Pinnigorgiols & Steroid & $\begin{array}{l}\text { Neutrophil superoxide and elastase } \\
\text { inhibition } \\
\text { (Anti-inflammatory and Cytotoxicity) }\end{array}$ & Chang et al., 2016b \\
\hline Nephthea erecta & $\begin{array}{l}\text { 24-methyl-cholesta- } \\
5,24(28) \text {-diene-3 } \underline{\beta}, 19- \\
\text { diol-7 } \underline{\beta} \\
\text {-monoacetate (MeCDDA) }\end{array}$ & Steroid & $\begin{array}{l}\text { Anti-small cell lung cancer } \\
\text { (Anti-inflammatory, Anti-fouling, Anti- } \\
\text { cancer) }\end{array}$ & Chung et al., 2017 \\
\hline $\begin{array}{l}\text { Nephthea } \\
\text { columnaris }\end{array}$ & Columnariols & Terpenoid & $\begin{array}{l}\text { Macrophage COX-2 and iNOS } \\
\text { expression inhibition (Anti-inflammatory } \\
\text { and Cytotoxicity) }\end{array}$ & Hsiao et al., 2015 \\
\hline Sinularia gaweli & Sinulacembranolide & Terpenoid & $\begin{array}{l}\text { Macrophage COX-2 and iNOS } \\
\text { expression inhibition (Anti-inflammatory) }\end{array}$ & Lin et al., 2015 \\
\hline Sinularia sp. & Sinulolides & Terpenoid & Inhibition of NF-KB activation & Yang et al., 2014 \\
\hline $\begin{array}{l}\text { Briareum } \\
\text { violacea }\end{array}$ & & Terpenoid & $\begin{array}{l}\text { Neutrophil superoxide and elastase } \\
\text { inhibition in response to } \\
\text { fMLP/CB (Anti-inflammatory) }\end{array}$ & Liaw et al., 2014 \\
\hline $\begin{array}{l}\text { Cespitularia } \\
\text { taeniata }\end{array}$ & Cespitulones & Terpenoid & $\begin{array}{l}\text { Cytotoxicity activities against human } \\
\text { medulloblastoma and colon } \\
\text { adenocarcinoma cancer cells } \\
\text { (Cytotoxicity) }\end{array}$ & Lin et al., 2014 \\
\hline Cladiella sp. & Cladieunicellins & Terpenoid & $\begin{array}{l}\text { Cytotoxicity activities against human } \\
\text { leukemia (Cytotoxicity) }\end{array}$ & Chen et al., 2014b \\
\hline $\begin{array}{l}\text { Sinularia } \\
\text { arborea. }\end{array}$ & Sinularbols & Terpenoid & $\begin{array}{l}\text { Neutrophil superoxide inhibition (Anti- } \\
\text { inflammatory) }\end{array}$ & Chen et al., 2014a \\
\hline Sarcophyton sp. & $\begin{array}{l}\text { Polyhydroxylated } \\
\text { steroids }\end{array}$ & Steroid & $\begin{array}{l}\text { Anti-H1N1 virus activities } \\
\text { (Cytotoxicity, Anti-viral) }\end{array}$ & Gong et al., 2013 \\
\hline Cladiella sp. & Cladieunicellin I & Terpenoid & $\begin{array}{l}\text { Cytotoxicity activities against DLD-1 } \\
\text { human colorectal adenocarcinoma cells } \\
\text { (Cytotoxicity) }\end{array}$ & Chen et al., 2013 \\
\hline
\end{tabular}




\begin{tabular}{|c|c|c|c|c|}
\hline $\begin{array}{l}\text { Sinularia } \\
\text { flexibilis }\end{array}$ & Flexibilin D & Terpenoid & $\begin{array}{l}\text { Macrophage COX-2 and iNOS } \\
\text { expression inhibition (Anti-inflammatory) }\end{array}$ & Hu et al., 2013a \\
\hline $\begin{array}{l}\text { Sinularia } \\
\text { flexibilis }\end{array}$ & 5-dehydrosinulariolide & Terpenoid & $\begin{array}{l}\text { Antitumor activities toward CAL- } 27 \text { and } \\
\text { A2058 cells }\end{array}$ & Hu et al., 2013b \\
\hline Sarcophyton sp. & 4'-OMe-asperphenamate & Alkaloid & Antifouling and antibacterial activity. & Zheng et al., 2013 \\
\hline Junceella fragilis & Frajunolides & Terpenoid & $\begin{array}{l}\text { Neutrophil superoxide and elastase } \\
\text { inhibition in response to } \\
\text { fMLP/CB (Anti-inflammatory) }\end{array}$ & Liaw et al., 2013 \\
\hline $\begin{array}{l}\text { Sinularia } \\
\text { flexibilis }\end{array}$ & Flexibilin B & Terpenoid & $\begin{array}{l}\text { Neutrophil elastase inhibition } \\
\text { (Anti-inflammatory) }\end{array}$ & Hu et al., 2013 \\
\hline $\begin{array}{l}\text { Scleronephthya } \\
\text { gracillimum }\end{array}$ & Sclerosteroids & Steroid & $\begin{array}{l}\text { Cytotoxicity activities against HepG2, } \\
\text { A549, and MDA-MB-231 cancer cell } \\
\text { line. } \\
\text { Macrophage COX-2 and iNOS } \\
\text { expression inhibition (Anti-inflammatory) }\end{array}$ & Fang et al., 2013 \\
\hline $\begin{array}{l}\text { Sinularia } \\
\text { querciformis }\end{array}$ & $\begin{array}{l}\text { 11-episinulariolide } \\
\text { acetate }\end{array}$ & Terpenoid & $\begin{array}{l}\text { Improved the histopathologic features } \\
\text { of human rheumatoid arthritis and } \\
\text { Macrophage COX-2 and iNOS } \\
\text { expression inhibition (Anti-inflammatory) }\end{array}$ & Lin et al., 2013 \\
\hline
\end{tabular}

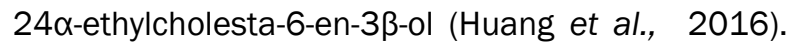
Moreover, secondary metabolites such as diterpenes, sesquiterpenes, furanoditerpenes, terpenoids, capnellenes and steroids from Lobophytum michaelae, Sinularia sarcophyton, Capnella sp., Dendronephthya sp., are responsible for inhibition of HIV infection, cytotoxic, antiinflammatory, anticancer and antimicrobial activity, as well as cardiac and vascular responses. More speciously, sesquiterpenes has anti-inflammatory activity which was isolated from Capnella imbricate, whereas anti-proliferative action adjacent to murine fibroblasts and cytotoxicity action against human leukemia and cervix carcinoma was shown by dihydroxycapnellene extracted from Dendronephthya rubeola (Rocha et al., 2011).

Though having significant roles of corals (Figure 1), their survivability is at risk because of their degradation and extinction caused by marine water pollution and various natural disasters. One of the major causes of these natural disasters is climate change which leads to factors like rising in sea level, the rise in temperature, reef calcification and solar radiation etc. These changes cause bleaching effect and severely affect phenotypes, reproduction, metabolism of the organisms (Magris et al., 2015). The trouncing of coral reef is also stirred due to the overfishing practices, aquaculture, and coastal development and to adjoin more in it, we comprise ocean acidification (Gurney et al., 2013). The most affected reasons for coral extermination is bleaching, predation, and diseases. The evolutionarily distinct and globally endangered (EDGE) has proved that the corals reefs have been losing their reef forming species (Huang, 2012). Another main phenomenon which further accelerates the devastating degradation of reefs is eutrophication. Every year the huge amount of fertilizer added to the crops fields, are washed away by run-off water to nearby reservoirs. This leads to an increased amount of nutrition is water, hence suitable condition for algal growth but adversely affects the coral growth and causes coral mortality (Gregg et al., 2013). Increasing climatic change and increase in the carbon dioxide level has caused the warming of the ocean and hence causes misbalancing in $\mathrm{pH}$ which points acidification, leading to coral bleaching and presently making it as endangered habitats (Anthony et al., 2011; Rocha et al., 2011; Kumari \& Mohan, 2018). Therefore the current review is prepared for providing the basic knowledge about how these underwater weenie life forms could be conserved by culturing as well as some of their biomedical benefaction to humankind as a whole.

\section{Conservation of coral reef}

Coral reefs are the chief constituents of several eco-chains, natural barriers, and more importantly, they are the pharmacy underwater and key to an enormous count of medicines and hence, it needs attention for their preservation. The damage due to environmental stresses may be mild, halfway or detrimental. According to the levels of stress impact, the management of coral reefs takes certain measure in favour of the coral reef protection. These management ensure that the conservation needs to be done first at a local scale level where people are more inclined on the coral reef for their usage and then finally, ecosystem's toughness could be improved (Anthony et al., 2015). For this several strategies should be followed by a common man such as to avoid striking or touching a coral reef, don't fish or boat near a coral reef populations, don't litter on the beach or in the ocean, don't purchase coral souvenirs, snorkel and scuba dive with care, 


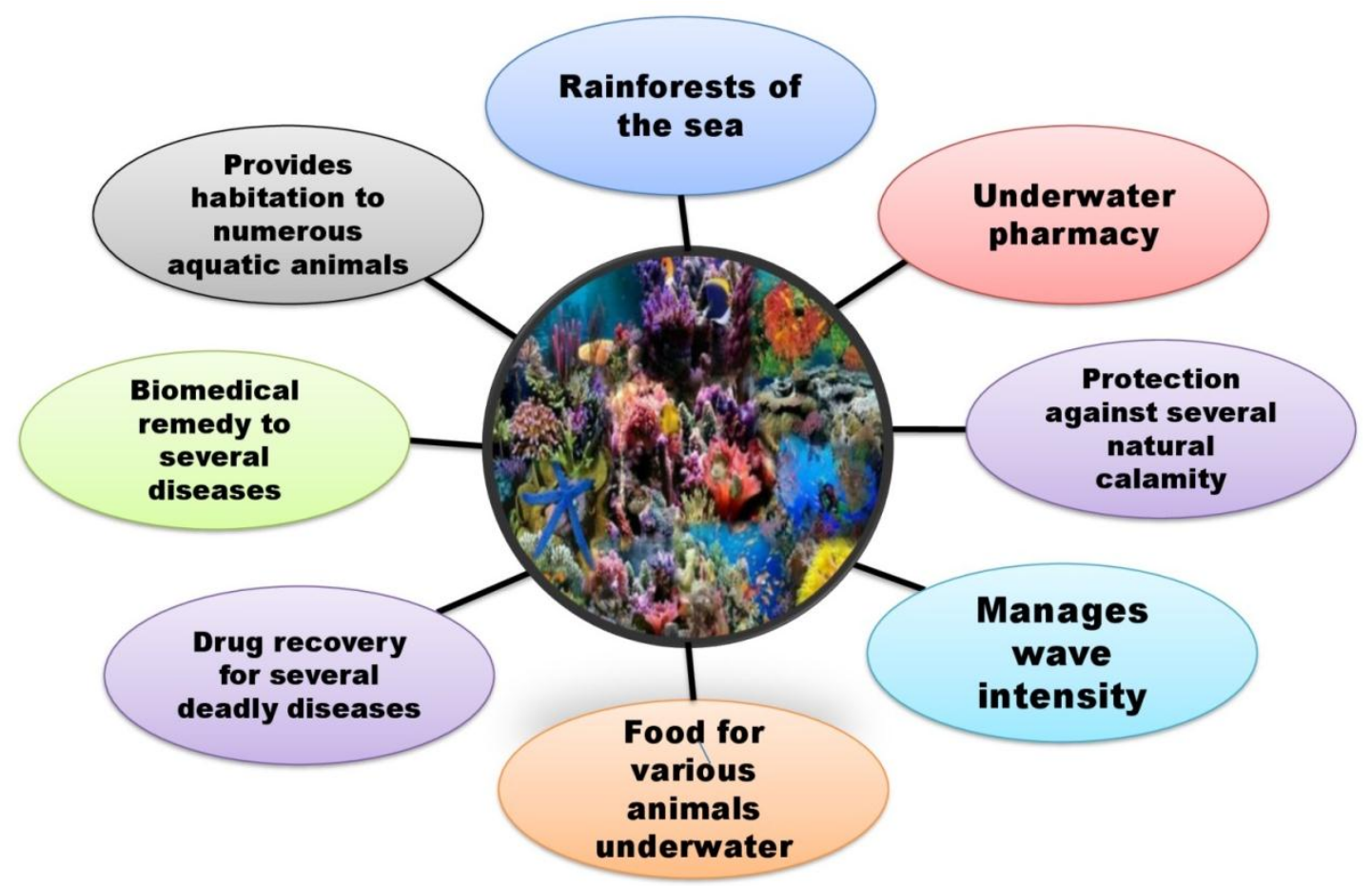

Fig. 1. Diversified importance of Coral reefs.

choose a hotel that embraces environmentalism and after all it needs to educate the local communities by different government and nongovernment organizations (Rinkevich, 2005; Saxena, 2015).

As natural restoration takes away too long, therefore, conservation by artificial methods is highly essential. A limited number of literature are found however according to Biggs (2013), the coral reef restoration completely depends on substratum stability and reestablishment of corals. In order to achieve the proper erected growth of corals, two reefs of Curacao were treated with coral rubble alone, rubble seeded with sponge fragments, rubble bound by concrete, and concrete "rubble" bound by concrete. This setup concluded that the use of rubble piles is very much supportive and appropriate for growth and reinstallation of sponges (Biggs, 2013).

\section{Culturing of coral reef}

Generally, marine resources are termed as 'blue gold' due to its abundant availability of diverse origin of heterogeneous bioactive clinically important compounds. But presently due to intense human interference with the marine life, the sustenance of these organisms is under critical condition. So in order to conserve this marine life and for its sustenance, it is necessary to neutralize or balance disrupted or destructed invertebrates by their cultivation. Though the significance of these invertebrate sea creatures is previously known still, its conservation through cultivation is not widely adopted. Hence, a necessary and fruitful step should be considered by the mankind. For culturing, initially needs to culture these weenie forms of life by understanding and neutralizing the factors responsible for its degradation. Some of the common degrading factors include physical disturbance, internal tides, erosion, sedimentation, predation, partial bleaching, and parasitism (Saxena, 2015). For growing strategies, it is essential to get access the available resources, required spaces, retaining reproductive capability and maturity (Riegl, 2009). Micro-colony fusion is an excellent coral aquaculture technique. Generally, rare coral species should be first considered for culture and restoration of the reefs. In this process, mini coral fragments are spaced equidistantly in cyanoacrylate gel with required nutrient and vitamins which results in their growth and development. Generally, growth of algae inhibits the coral reefs, therefore Trochus inextus and Tripneustes gratilla are used to control algal growth (Forsman et al., 2015).

Presently aquaculture leads as a technique through which desired marine invertebrates are cultured either in situ or ex situ. The in situ or mariculture is a culturing process of desired 
invertebrates including reefs in natural conditions. The factors affecting this process are flow of water, hydrodynamics, light, nutrients, etc. whereas ex situ is done under controlled climatic condition, which is quite expensive where manpower also plays a significant role in the collection of the cultured products (Pomeroy et al., 2006; Lirman \& Schopmeyer, 2016). However, ex situ cultivation has major advantages over in situ cultivation, in many different ways like single species can grow under a controlled condition which estimates the amount of required nutrients, vitamins, optimum $\mathrm{pH}$, ion concentration. Moreover, the presence of diversified bioactive, pharmaceutically beneficiary compound as well as their quantity could be accurately evaluated. Again, the limitations associated with the natural growth and development of these sea creatures could also be assessed and eliminated. Specifically, some of the commonly associated limitations such as required time duration, viral infection, and inability to reproduce by the cell to cell interactions under harsh marine environmental condition could be better studied and understood (Rinkevich \& Shafir, 2000; Rocha et al., 2015; Leal et al., 2016).

\section{Applications in biomedical field}

Corals have widespread application in the biomedical sphere. From extraction of steroids to the production of several potent medications for diseases like several organ oriented cancers, neurodegenerative diseases like Parkinson's and Alzheimer's disorder, arthritis, acquired immune deficiency syndrome (AIDS), malaria etc. (Cooper et al., 2014; Ganguly, 2016). The calcifying nature of the polyps also helps in the calcinations of bones and teeth. Coral reefs have an ethnobotany to play in the production of potential medicines which cures strokes, head injury, artery bypass surgery, chronic pain of cancer, and peripheral neuropathies (Alves \& Rosa, 2007). The never ending list runs along with other diseases like hypertension, cardiovascular, injuries related to head, etc. This is all made possible by the venom of cone snails, of which approximately 500 species dwelling in the coral reef of the tropics (Peters, 2013). With this many applications, the "tropical rainforests of the sea" have definitely a great deal to do in the biomedical field however, various properties of major diseases are described below.

\section{Arthritis}

The main reason for rheumatoid arthritis, sclerosis, or asthma is basically inflammation. So, before proceeding towards arthritis, its initiation in form of inflammation should be acknowledged. This inflammatory response is generally shown by macrophages, mast cells, and dendritic cells, when tissues are injured by bacteria, trauma, toxins, heat, or any other cause. There are two forms of inflammation namely; acute inflammation and chronic inflammation, which later on cause the pathological diseases including cancer, sclerosis, asthma or arthritis (Ashley et al., 2012). In last few years, soft corals like Cladiella and Klyxum have been a great source of eunicellin-based diterpenes (Liang et al., 2008). These diterpenes include krempfielins, hirsutalins, klymollins, klysimplexin, klysimplexin sulfoxide, simplexin, and cladieunicellin hold a major anti-inflammatory property. Further, corals like Briareum and Pachyclavularia also produce diterpenoid and mostly inhibit superoxide generation (Gonzalez et al., 2015). Sinulariolide acetate produced by Sinularia ouerciformis, when injected into the rat, as a therapy for arthritis showed promising results. It is believed to do wonders in humans as well, and prevent this chronic inflammatory disease of rheumatoid arthritis (Cooper et al., 2014). The gorgonian species Euplexaura flava secrete anti-inflammatory butanolide lipid and anti-inflammatory briarane-type diterpene whereas, excavatolide $B$ is extracted from Taiwanese gorgonian coral Briareum excavatum (Rocha et al., 2011; Lin et al., 2017).

\section{Cancer}

While the hunt for cancer remedies was going on, meanwhile in the 1950's sponges were experimented and found that an anti-cancer agent known as ara-C (Cytarabine) was the first to be derived by the marine sponge called Cryptotethya crypta. With the successful implementation as a drug, it cured lymphoma, leukemia, as well as lung, pancreatic, bladder and breast cancer (Anjum et al., 2016). Extracts of soft corals such as Cladiella australis, Clavularia viridis and Klyxum simplex were also able to inhibit the growth of human oral squamous and carcinoma cells (Liang et al., 2008). Bioassay-guided fractionations of Sarcophyton sp. and Lobophytum sp., provide the information about some of the known antitumor promoters. These antitumor promoters include cembrane diterpenoid, (+)-sarcophytol-A as well as lobane diterpenoid, carbomethoxyfuscol from Sarcophyton sp. and cembranoid, crassumolide E from Lobophytum sp. (Bonnard et al., 2010). Some of the species like Sinularia ouerciformis and Nephthea chabrolii yield important cytotoxic exhibiting steroids such as nebrosteroids Q, R, and S which are fruitful therapy for different cancer (Cooper et al., 2014). Some compounds are obtained from soft corals which are rich in anti-cancer activity namely malformin $A$, kuanoniamine $\mathrm{D}$, hymenialdisine, and gallic acid (Dobretsov et al., 2016). Oncologists also used 
compound like capnell-9(12)-ene- $8 \beta, 10 \alpha$-diol, which prevents the transcription factor Myc with the help of its partner protein Max that causes good cytotoxicity against the cancer cell. Cytotoxicity of human hepato-cellular carcinoma, human breast carcinoma, human lung carcinoma, and human gingival carcinoma is terminated by Klysimplexin $B$ and Klysimplexin $\mathrm{H}$, which is extracted from Klyxum simplex (Rocha et al., 2011).

\section{AIDS}

Despite a large number of applications, the research related to extracting or isolation of therapeutics against AIDS is limited. However, corals like Sinularia heterospiculata, Sinularia maxima and Litophyton arboreum have been reported having inhibitory activity against human immunodeficiency virus (Ellithey et al., 2014). Another report says about the discovery of a new protein, called cnidarins which supports blocking of HIV infection (Anonymous, 2017).

\section{Bone and tooth regeneration}

Marine products are nowadays frequently utilized in regenerating oral tissues, augmenting craniofacial tissues, replacing dysfunctional dentine and bone. The bioactive metabolites which are to be achieved for the regeneration purpose are cloned. For teeth regeneration generally two ways are followed, which includes either directly filling of the sample into the affected part where it will further grow into the desired part or culturing the tissues and then transplanting on spot. The marine products not only help in the regeneration but also protect the newly formed product from bacterial attack (Green et al., 2014). The aragonite and calcite present in the hard and soft corals respectively, containing the calcium part are now used in the repairing and regeneration of both bones and teeth (Cooper et al., 2014). A hydrocoral (Millepora dichotama) constructs a skeleton out of aragonite, and this species has a remarkable growth rate which helps in the increase in cloning speed and hence can be used in bone grafting. For the purpose of generation of skeleton, $M$. dichotama acts as a biolattice in neural tissue engineering. The coral Porites lutea was potential enough to form hippocampus neurons in its exoskeleton (Razak \& Hoeksema, 2003; Vago, 2008). Hydroxyapatite being a major component of bone mineral and coral is truly beneficial in bone grafting, auto grafting, osteoconductivity and bone tissue integration (Vago, 2008). Several coral genus are used as bone substitutes because of their calcium carbonate secretion, namely Pocillopora, Acropora, Montipora, Porites, Goniopora, Fungia,
Polyphyllia, Favites, Acanthastrea, Lobophyllia, and Turbinaria (Parizi et al., 2013).

\section{Neurodegenerative disease}

Neurodegenerative disease like Parkinson's disease can be cured by a compound, 11dehydrosinularolide which is extracted from corals (Chen et al., 2012). A soft coral, Sinularia flexibilis releases a terpenoid (11-dehydrosinulariolide), which also cures this neurodegenerative disorder (Grosso et al., 2014). This disease is dangerous as leads to memory loss and lack of sensory input. Steroids like $(3 \beta, 4 \alpha, 5 \alpha, 8 \beta, 11 \beta)-4$-methylergost24(28)-ene-3,8,11-triol and ergost-4,24(28)-diene-3one from soft coral Sinularia depressa is effective against this disease (Grosso et al., 2014). Bioactive compounds from Clavularia sp. also acts as a neurotrophic factor on the nervous system and can prevent Alzheimer's disease by synthesizing acetylcholine (Rocha et al., 2011). Chitin being the major component of corals, the derived chitosan has effects on neurodegenerative diseases as well as anti-tumour properties. B-amyloid and acetylcholinesterase has anti-neuroinflammatory effect which was reported by Hao et al. (2017).

\section{Antiprotozoal activity}

From the Vietnamese sea, 34 cembranes extracted from different species like Lobophytum crassum, Lobophytum laevigatum, and Sinularia maxima which were found to possess antiprotozoal activity. Compounds of 7S,8S-epoxy-1,3,11cembratriene-16-oic methyl ester, (1R,4R,2E,7E,11E)-cembra-2,7,11-trien-4-ol, crassumol D, crassumol E, (1S,2E,4S,6E,8S,11S)2,6,12(20)-cembrantriene-4,8,11-triol and their different derivatives from these soft corals have effective antiprotozoal activity against Trypanosoma brucei rhodesiense, Trypanosoma cruzi, Leishmania donovani and Plasmodium falciparum under in vitro experimental condition (Thao et al. 2015). Pseudopterogorgia bipinnata was as considered as anti-malarial agent due to the presence of potent compound caucanolides A-F (Ospina et al., 2005).

\section{Conclusion}

It is righteously quoted that, "the part that is discovered is minimal, and the gigantic part is yet to be discovered". This statement corresponds to the present day situation of the marine environment. The present researchers are settling down and getting content with the lesser land but the humongous marine flora and fauna that are yet to be discovered. The marine biotas are completely neglected though they provide an enormous source 
of medicinal derivatives, secondary metabolites and cure to several diseases, which are evidenced from above described points that to be in favour of corals only. Due to enormous medicinal benefits, sometimes they are named as blue gold/ pharmaceuticals supplies/ medicinal storehouse/ and many more. Therefore such immense treasure should be preserved and cultured in maximum in order to fight the devastating impacts of ocean acidification, high tidal waves, etc. This mishap should be avoided and action should be taken against its devastation so that such beneficial gift of nature should be protected. Meanwhile, strategies should be taken to familiarize these natural products among common people by enhancing its entry to the drug market.

\section{References}

Alves, R.R.N. \& Rosa, L.M.L. 2007. Biodiversity, traditional medicine and public health: where do they meet. J. Ethnobiol. Ethnomed. 3(14):19. doi : 10.1186/1746-4269-3-14

Anjum, K., Abbas, S.Q., Shah \& S.A.A. 2016. Akhter, N., Batool, S., and Hassan, S.S.U., Marine sponges as a drug treasure. Biomol. Ther. 24(4): $\quad 347-362$.

10.4062/biomolther.2016.067

Anonymous. 2017. Coral reefs provide potent new anti-HIV proteins. American Society for Biochemistry and Molecular Biology, ScienceDaily, www.sciencedaily.com/releases/ 2014/04/140429092649.htm.

Anthony, K., Marshall, P.A., Abdulla, A., Beeden, R., Bergh, C., Black, R., Eakin, C.M., Game, E.T., Gooch, M., Graham, N.A. \& Green, A., 2015. Operationalizing resilience for adaptive coral reef management under global environmental change. Global change Biology. 21(1):48-61. doi: $10.1111 /$ gcb.12700

Anthony, K., Maynard, J.A., Diaz-Pulido, G., Mumby, P.J., Marshall, P.A., Cao, L. \& Hoegh, G.O. 2011. Ocean acidification and warming will lower coral reef resilience. Global Change Biol. 17(5):1798-1808. doi: 10.1111/j.13652486.2010.02364.x

Ashley, N.T., Weil, Z.M. \& Nelson, R.J. 2012. Inflammation: mechanisms, costs, and natural variation. Annu. Rev. Ecol. Evol. Syst. 43: 385406. doi: 10.1146/annurev-ecolsys-040212092530

Biggs, B.C. 2013. Harnessing natural recovery processes to improve restoration outcomes: an experimental assessment of sponge-mediated coral reef restoration. PLOS ONE 8(6):1-15. doi : 10.1371/journal.pone.0064945

Bonnard, I., Jhaumeer-Laulloo, S.B., Bontemps, N., Banaigs, B. \& Aknin, M. 2010. New lobane and cembrane diterpenes from two comorian soft corals. Mar. Drugs. 8(2):359-372. doi: 10.3390/md8020359

Cao, F., Shao, C.L., Liu, Y.F., Zhu, H.J. \& Wang, C.Y. 2017. Cytotoxic serrulatane-type diterpenoids from the Gorgonian Euplexaura sp. and their absolute configurations by vibrational circular dichroism. Sci. Rep. 7(1):1-8. doi: 10.1038/s41598-017-12841-2

Chang, Y.C., Hwang, T.L., Sheu, J.H., Wu, Y.C. \& Sung, P.J. 2016a. New anti-inflammatory 9,11secosterols with a rare tricyclo $[5,2,1,1]$ decane ring from a Formosan Gorgonian Pinnigorgia sp. Mar. Drugs 14(12):p218. doi: 10.3390/md14120218

Chang, Y.C., Kuo, L.M., Hwang, T.L., Yeh, J., Wen, Z.H., Fang, L.S., Wu, Y.C., Lin, C.S., Sheu, J.H. \& Sung, P.J. 2016b. Pinnisterols A-C, new 9,11secosterols from a gorgonian Pinnigorgia $\mathrm{sp}$. Mar. Drugs 14(1):p12. doi : 10.3390/md14010012.

Chang, Y.T., Huang, C.Y., Tang, J.Y., Liaw, C.C., Li, R.N., Liu, J.R., Sheu, J.H. \& Chang, H.W. 2017b. Reactive oxygen species mediate soft coralsderived sinuleptolide-induced antiproliferation and DNA damage in oral cancer cells. Onco. Targets. Ther. 10: 3289-3297. doi: 10.2147/OTT.S138123

Chao, C.H., Li, W.L., Huang, C.Y., Ahmed, A.F., Dai, C.F., Wu, Y.C., Lu, M.C., Liaw, C.C. \& Sheu, J.H. 2017. Isoprenoids from the soft coral Sarcophyton glaucum. Mar. Drugs 15(7):202. doi: 10.3390/md15070202

Chao, C.H., Wu, C.Y., Huang, C.Y., Wang, H.C., Dai, C.F., Wu, Y.C. \& Sheu, J.H. 2016. Cubitanoids and cembranoids from the soft coral Sinularia nanolobata. Mar. Drugs 14(8):150. doi: 10.3390/md14080150

Chen, K.H., Dai, C.F., Hwang, T.L., Chen, C.Y., Li, J.J., Chen, J.J., Wu, Y.C., Sheu, J.H., Wang, W.H. \& Sung, P.J. 2014a. Discovery of novel diterpenoids from Sinularia arborea. Mar. Drugs 12(1):385-393. doi: 10.3390/md12010385

Chen, T.H., Chen, W.F., Wen, Z.H., Lu, M.C., Wang, W.H., Li, J.J., Wu, Y.C. \& Sung, P.J. 2014b. Cladieunicellins $\mathrm{M}-\mathrm{Q}$, new eunicellins from Cladiella sp. Mar. Drugs 12(4):21442155. doi: $10.3390 / m d 12042144$ 
Chen, T.H., Lu, M.C., Chang, Y.C., Su, Y.D., Chen, Y.H., Lin, N.C., Fang, L.S., Wu, Y.C. \& Sung, P.J. 2013. Discovery of new eunicellin-based diterpenoids from a formosan soft coral Cladiella sp. Mar. Drugs 11(11):4585-4593. doi: $10.3390 / \mathrm{md} 11114585$

Chen, W.F., Chakraborty, C., Sung, C.S., Feng, C.W., Jean, Y.H., Lin, Y.Y., Hung, H.C., Huang, T.Y., Huang, S.Y., Su, T.M., Sung, P.J., Sheu, J.H. \& Wen, Z.H. 2012. Neuroprotection by marinederived compound, 11-dehydrosinulariolide, in an in vitro Parkinson's model: a promising candidate for the treatment of Parkinson's disease. Naunyn Schmiedebergs Arch. Pharmacol. 385(3):265-275. doi: 10.1007/s00210-011-0710-2

Chung, T.W., Su, J.H., Lin, C.C., Li, Y.R., Chao, Y.H., Lin, S.H. \& Chan, H.L. 2017. 24-methylcholesta-5,24(28)-diene-3 $\beta, 19-$ diol-7- $\beta$ monoacetate inhibits human small cell lung cancer growth in vitro and in vivo via apoptosis induction. Mar. Drugs. 15(7):210. doi: 10.3390/md15070210

Cooper, E.L., Hirabayashi, K., Strychar, K.B., \& Sammarco, P.W. 2014. Corals and their potential applications to integrative medicine. J. Evid. Based Complementary Altern. Med. pp 19. doi: 10.1155/2014/184959

Dobretsov, S., Tamimi, Y., Al-Kindi, M.A. \& Burney, I. 2016. Screening for anti-cancer compounds in marine organisms in Oman. Sultan Qaboos University Med. J. 16(2):168-174. doi: 10.18295/squmj.2016.16.02.006

Ellithey, M.S., Lall, N., Hussein, A.A. \& Meyer, D. 2014. Cytotoxic and HIV-1 enzyme inhibitory activities of Red Sea marine organisms. BMC Complem. Altern. Med. 14(77):1-8. doi: 10.1186/1472-6882-14-77.

Fang, H.Y., Hsu, C.H., Chao, C.H., Wen, Z.H., Wu, Y.C., Dai, C.F. \& Sheu, J.H. 2013. Cytotoxic and antiinflammatory metabolites from the soft coral Scleronephthya gracillimum. Mar. Drugs 11(6): 1853-1865. doi: 10.3390/md11061853

Forsman, Z.H., Page, C.A., Toonen, R.J. \& Vaughan, D. 2015. Growing coral larger and faster: microcolony-fusion as a strategy for accelerating coral cover. Peer J. 3:e1313. doi: 10.7717/peerj.1313

Ganguly, S. 2016. Coral reefs: a review on its environmental and biomedical prospects with conservation efforts. Int. J. Pure App. Biosci. 4(1):166-167. doi: 10.18782/23207051.2181
Gong, K.K., Tang, X.L., Zhang, G., Cheng, C.L., Zhang, X.W., Li, P.L. \& Li, G.Q. 2013. Polyhydroxylated steroids from the South China sea soft coral Sarcophyton sp. and their cytotoxic and antiviral activities. Mar. Drugs 11(12):47884798. doi: 10.3390/md11124788

Gonzalez, Y., Mendoza, D.T., Jones, G.E., \& Fernandez, P.L. 2015. Marine diterpenoids as potential anti-inflammatory agents. Mediators Inflamm. 2015:263543. doi: $10.1155 / 2015 / 263543$

Green, D.W., Lai, W.F., Jung, H.S. 2014. Evolving marine biomimetics for regenerative dentistry. Mar. Drugs 12(5):2877-2912. doi: 10.3390/md12052877

Gregg, A.K., Hatay, M., Haas, A.F., Robinett, N.L., Barott, K., Vermeij, M.J.A., Marhaver, K.L., Meirelles, P., Thompson, F. \& Rohwer, F. 2013. Biological oxygen demand optode analysis of coral reef-associated microbial communities exposed to algal exudates. Peer J. 1:e107. doi: 10.7717/peerj.107

Grosso, C., Valentao, P., Ferreres, F. \& Andrade, P.B. 2014. Bioactive marine drugs and marine biomaterials for brain diseases. Mar. Drugs. 12(5):2539-2589. $10.3390 / \mathrm{md} 12052539$

Gurney, G.G., Thomas, J.M., Geronimo, R.C., Alino, P.M. \& Johnson, C.R. 2013. Modelling coral reef futures to inform management: can reducing local-scale stressors conserve reefs under climate change. PLoS ONE 8(11):e80137.

Hao, C., Wang, W., Wang, S., Zhang, L. \& Guo, Y. 2017. An overview of the protective effects of chitosan and acetylated chitosan oligosaccharides against neuronal disorders. Mar. Drugs 15(4):89. doi: 10.3390/md15040089

Hsiao, T.H., Sung, C.S., Lan, Y.H., Wang, Y.C., Lu, M.C., Wen, Z.H., Wu, Y.C. \& Sung, P.J. 2015. New anti-inflammatory cembranes from the cultured soft coral Nephthea columnaris. Mar. Drugs 13(16):3443-3453. doi: 10.3390/md13063443

Hu, L.C., Su, J.H., Chiang, M.Y.N., Lu, M.C., Hwang, T.L., Chen, Y.H., Hu, W.P., Lin, N.C., Wang, W.H., Fang, L.S., Kuo, Y.H. \& Sung, P.J. 2013a. Flexibilins A-C, new cembrane-type diterpenoids from the formosan soft coral, Sinularia flexibilis. Mar. Drugs 11(6):19992012. doi: 10.3390/md11061999

Hu, L.C., Yen, W.H., Su, J.H., Chiang, M.Y.N., Wen, J.H., Chen, W.F., Lu, T.J., Chang, Y.W., Chen, 
Y.H., Wang, W.H., Wu, Y.C. \& Sung, P.J. 2013b. Cembrane derivatives from the soft corals, Sinularia gaweli and Sinularia flexibilis. Mar. Drugs 11(6):2154-2167. doi: 10.3390/md11062154

Huang, C.H., Chang, C.W., Tseng, Y.J., Lee, J., Sung, P.J., Su, J.H., Hwang, T.L., Dai, C.F., Wang, H.C. \& Sheu, J.H. 2016. Bioactive steroids from the formosan soft coral Umbellulifera petasites. Mar. Drugs 14(10):180. doi: $10.3390 / \mathrm{md} 14100180$

Huang, C.Y., Su, J.H., Liaw, C.C., Sung, P.J., Chiang, P.L., Hwang, T.L., Dai, C.F. \& Sheu, J.H. 2017. Bioactive steroids with methyl ester group in the side chain from a reef soft coral Sinularia brassica cultured in a tank. Mar. Drugs 15(9): 280. doi: $10.3390 / \mathrm{md} 15090280$

Huang, C.Y., Sung, P.J., Uvarani, C., Su, J.H., Lu, M.C., Hwang, T.L., Dai, C.F., Wu, S.L. \& Sheu, J.H. 2015. Glaucumolides A and B, biscembranoids with new structural type from a cultured soft coral Sarcophyton glaucum. Sci. Rep. 5: 15624. doi: 10.1038/srep15624

Huang, D. 2012. Threatened reef corals of the World. PLOS ONE 7: e34459. doi: 10.1371/journal.pone.0034459

Krediet, C.J., Ritchie, K.B., Paul, V.J. \& Teplitski, M. 2013. Coral-associated micro-organisms and their roles in promoting coral health and thwarting diseases. Proc. R. Soc. B 280(1755): 20122328. doi: 10.1098/rspb.2012.2328

Kumari, R.K. \& Mohan, P.M. 2018. Review on dissolved organic carbon and particulate organic carbon in marine environment. IImu. Kelautan. 23(1):25-36. doi: 10.14710/ik.ijms.23.1.25-36

Kvitt, H., Winter, E.K., Landaw, K.M., Zandbank, K., Kushmaro, A., Rosenfeld, H., Fine, M. \& Tchernov, D. 2015. Breakdown of coral colonial form under reduced $\mathrm{pH}$ conditions is initiated in polyps and mediated through apoptosis. Proc. Natl. Acad. Sci. USA 112(7):2082-2086. doi: 10.1073/pnas.1419621112

Leal, M.C., Ferrier-Pagès, C., Petersen, D. \& Osinga, R., 2016. Coral aquaculture: applying scientific knowledge to ex situ production. Reviews Aquacul. 8(2):136-153. doi: $10.1111 / \mathrm{raq} .12087$

Liang, C., Wang, G., Liaw, C., Lee, M., Wang, S., Cheng, D. \& Chou, T. 2008. Extracts from Cladiella australis, Clavularia viridis and Klyxum simplex (Soft Corals) are capable of inhibiting the growth of human oral squamous cell carcinoma cells. Mar. Drugs 6(4):595-606. doi: 10.3390/md6040595

Liaw, C.C., Cheng, Y.B., Lin, Y.S., Kuo, Y.H., Hwang, T.L. \& Shen, Y.C. 2014. New briarane diterpenoids from Taiwanese soft coral Briareum violacea. Mar. Drugs. 12(8):46774692. doi: $10.3390 / m d 12084677$

Liaw, C.C., Lin, Y.C., Lin, Y.S., Chen, C.H., Hwang, T.L. \& Shen, Y.C. 2013. Four new briarane diterpenoids from Taiwanese Gorgonian Junceella fragilis. Mar. Drugs 11(6):20422053. doi: $10.3390 / m d 11062042$

Lin, W.J., Wu, T.Y., Su, T.R., Wen, Z.H., Chen, J.J., Fang, L.S., Wu, Y.C. \& Sung, P.J. 2015. Terpenoids from the octocoral Sinularia gaweli. Int. J. Mol. Sci. 16(8):19508-19517. doi: 10.3390/ijms160819508

Lin, Y.C., Wang, S.S., Chen, C.H., Kuo, Y.H. \& Shen, Y.C. 2014. Cespitulones A and B, cytotoxic diterpenoids of a new structure class from the soft coral Cespitularia taeniata. Mar. Drugs 12(6):3477-3486. 10.3390/md12063477

Lin, Y.Y., Jean, Y.H., Lee, H.P., Chen, W.F., Sun, Y.M., Su, J.H., Lu, Y., Huang, S.Y., Hung, H.C., Sung, P.J., Sheu, J.H. \& Wen, Z.H. 2013. A soft coralderived compound, 11-epi-sinulariolide acetate suppresses inflammatory response and bone destruction in adjuvant-induced arthritis. PLOS ONE 8(5):1-11. doi: 10.1371/journal.pone.0062926

Lin, Y.Y., Jean, Y.H., Lee, H.P., Lin, S.C., Pan, C.Y., Chen, W.F., Wu, S.F., Su, J.H., Tsui, K.H., Shea, J.H., Sung, P.J., Wen, Z.H. 2017. Excavatolide B attenuates rheumatoid arthritis through the inhibition of osteoclastogenesis. Mar. Drugs 15: 9. doi: 10.3390/md15010009

Lirman, D. \& Schopmeyer, S. 2016. Ecological solutions to reef degradation: optimizing coral reef restoration in the Caribbean and Western Atlantic. Peer. J. 4:1-19.

Magris, R.A., Heron, S.F. \& Pressey, R.L. 2015. Conservation planning for coral reefs accounting for climate warming disturbances. PLOS ONE 10(11): 1-26. doi: 10.7717/peerj. 2597

Malve, H. 2016. Exploring the ocean for new drug developments: Marine pharmacology. J. Pharm. Bioallied Sci. 8(2):83-91. doi: 10.4103/09757406.171700

Ospina, C.A., Rodríguez, A.D., Sánchez, J.A., OrtegaBarria, E., Capson, T.L. \& Mayer, A.M.S. 2005. 
Caucanolides A-F, unusual antiplasmodial constituents from a Colombian collection of the gorgonian coral Pseudopterogorgia bipinnata. J. Nat. Prod. 68(10):1519-1526. doi: 10.1021/np050239z

Parizi, A.M., Oryan. A., Sarvestani, Z.S. \& Sadegh, A.B. 2013. Effectiveness of synthetic hydroxyapatite versus Persian Gulf coral in an animal model of long bone defect reconstruction. J. Orthopaed. Traumatol. 14(4): 259-268. doi: 10.1007/s10195-013-0261-z

Peters, H. 2013. Cone snails a significant biomedical resource at risk. PhD thesis. University of York, UK. pp. 1-139.

Pomeroy, R.S., Parks, J.E. \& Balboa, C.M. 2006. Farming the reef: is aquaculture a solution for reducing fishing pressure on coral reefs? Mar. Policy 30(2):111-130. doi: 10.1016/j.marpol.2004.09.001

Razak, T.B. \& Hoeksema, B.W. 2003. The hydrocoral genus Millepora (Hydrozoa: Capitata: Milleporidae) in Indonesia. Zool. Verh. Leiden 345:313-336.

Riegl, B., Bruckner, A., Coles, S.L., Renaud, P. \& Dodge, R.E. 2009. Coral reefs: threats and conservation in an era of global change. Ann. N. Y. Acad. Sci. 1162: 136-186. doi: 10.1111/j.1749-6632.2009.04493.x

Rinkevich, B. \& Shafir, S. 2000. Ex situ culture of colonial marine ornamental invertebrates: concepts for domestication. Aquarium Sci. Conserv. 2(4):237-250. doi: 10.1023/A:1009664907098

Rinkevich, B. 2005. Conservation of coral reefs through active restoration measures: Recent approaches and last decade progress. Environ. Sci. Technol. 39(12):4333-4342. doi: 10.1021/es0482583

Rocha, J., Peixe, L., Gomes, N.C.M. \& Calado, R. 2011. Cnidarians as a source of new marine bioactive compounds-an overview of the last decade and future steps for bioprospecting. Mar. Drugs 9(10):1860-1886. doi: 10.3390/md9101860

Rocha, J.M., Bontas, B., Cartaxana, P., Leal, M.C.,
Ferreira, J.M., Rosa, R., Serodio, J. \& Calado, R. 2015. Development of a standardized modular system for experimental coral culture. J. World Aquacult. Soc. 46(3):235-251. doi: 10.1111/jwas.12186

Saxena, A. 2015. Coral reefs and their conservation a review. Biol. Chem. Res. 2015:187-206

Su, Y.D., Sung, C.S., Wen, Z.H., Chen, Y.H., Chang, Y.C., Chen, J.J., Fang, L.S., Wu, Y.C., Sheu, J.H. \& Sung, P.J. 2016. New 9-hydroxybriarane diterpenoids from a Gorgonian coral Briareum sp. (Briareidae). Int. J. Mol. Sci. 17(1):79. doi: 10.3390/ijms17010079

Su, Y.D., Wu, T.Y., Wen, Z.H., Su, C.C., Chen, Y.H., Chang, Y.C., Wu, Y.C., Sheu, J.H. \& Sung, P.J. 2015. Briarenolides U-Y, new antiinflammatory briarane diterpenoids from an octocoral Briareum sp. (Briareidae). Mar. Drugs 13(12):7138-7149. 10.3390/md13127060

Thao, N.P., Luyen, B.T.T., Brun, R., Kaiser, M., Kiem, P.V., Minh, C.V., Schmidt, T.J., Kang, J.S. \& Kim, Y.H. 2015. Anti-protozoal activities of cembrane-type diterpenes from Vietnamese soft corals. Molecules 20(7):12459-12468. doi: 10.3390/molecules200712459

Vago, R. 2008. Beyond the skeleton: Cnidarian biomaterials as bioactive extracellular microenvironments for tissue engineering. Organogenesis 4(1):18-22.

Whuang, T.Y., Tsai, H.C., Su, Y.D., Hwang, T.S. \& Sung, P.J. 2017. Sterols from the Octocoral Nephthea columnaris. Mar. Drugs 15(7):212. doi: $10.3390 / \mathrm{md} 15070212$

Yang, B., Wei, X., Huang, J., Lin, X., Liu, J., Liao, S., Wang, J., Zhou, X., Wang, L. \& Liu, Y. 2014. Sinulolides $\mathrm{A}-\mathrm{H}$, new cyclopentenone and butenolide derivatives from soft coral Sinularia sp. Mar. Drugs 12(10):5316-5327. doi: 10.3390/md12105316

Zheng, C.J., Shao, C.L., Wu, L.Y., Chen, M., Wang, K.L., Zhao, D.L., Sun, X.P., Chen, G.Y. \& Wang, C.Y. 2013. Bioactive phenylalanine derivatives and cytochalasins from the soft coral-derived fungus, Aspergillus elegans. Mar. Drugs 11(6): 2054-2068. doi: 10.3390/md11062054 